\title{
THE COMPREHENSION OF RELATIVE CLAUSES BY MONOLINGUAL AND BILINGUAL SPEAKERS OF PORTUGUESE AND ENGLISH
}

\section{Marcus Maia \& Juliana Maia"}

Abstract: The present study investigates the comprehension of Portuguese and English ambiguous relative sentences by native and L2 learners of both English and Portuguese. Our preliminary results in an offline questionnaire seem to indicate that Universal Grammar principles may not be directly accessible to adult L2 learners as it is to child L1 learners because $\mathrm{L} 1$ processing strategies may be influencing the comprehension of L2 input.

Keywords: Psycholinguistics; sentence processing; second language acquisition; relative clauses

This paper presents a pilot offline study on relative clause attachment preferences of native and non-native speakers of English and Portuguese in order to have a preliminary assessment on the processing interferences between these languages. Similar studies have been carried out on languages such as English and Spanish, but we know of no studies to date on processing interferences between English and Portuguese.

It is a well known fact that adult learners of a second language (L2) do not usually display the same proficiency as younger learners. Within the framework of the Principles and Parameters theory (Chomsky, 1981; Chomsky \& Lasnik, 1993), it is assumed that language learning can be conceived of as a parameter setting process, through which the innate principles of Universal Grammar (UG) are set according to the environmental data the child is exposed to. Accessibility to such innate principles offers a logical explanation to the poverty of stimulus

(*) Marcus Maia is an adjunct professor of Linguistics in the department of Anthropology of the National Museum and in the graduate program of Linguistics of UFRJ; Juliana Meyohas Maia is an undergraduate student in UFRJ and has a junior scholarship (CNPq) through the Laboritory of Language and Cognition (UFRJ-CNPq). 
problem. Despite the underdetermination of the data, due to the guidance of UG principles, languages can be acquired by children in a spontaneous, relatively rapid and uniform way. Fernandez (1999) proposes that adult learners of a second language are not equally successful in their task because their access to UG is influenced by the processing strategies specific to their first language (L1). According to Fernandez (1999), because of processing interference adult learners usually do not attain the adequate knowledge to develop the underlying grammatical representations of the target L2. If the parsing strategies employed by L2 learners are inadequate, they may be missing important information to acquire the grammatical system in the second language. Crucially, it should be noted that this hypothesis attributes the lack of success in internalizing the grammar of an L2 not to a lack of access to UG in itself, but to a solidified, automatic perceptual routine which is suited to parse L1 input but not to parse L2 input. This possibility leads Fernandez to investigate whether adult learners process L2 linguistic input in the way monolingual speakers of the target language do.

In her study, Fernandez focusses on a type of linguistic structure which has been considered in the psycholinguistic literature at least since Cuetos \& Mitchell (1988) influential research on the universality of the human sentence processing mechanism or parser. The sentences of this type have the form NP1 of NP2 RC, as exemplified in (1):

(1) Someone shot the servant of the actress [who was on the balcony].

\section{NP1 NP2 RC}

Cuetos and Mitchell's (1988) comparative research on the comprehension of ambiguous relative clauses in Spanish and in English showed that there are cross-linguistic differences in the syntactic processing of these sentences, challenging the universality of Frazier's (1979) Late Closure strategy, which had been established on the basis of English data alone. Together with Minimal Attachment and other principles, Late Closure is part of Frazier's Garden Path theory which aims to explain how the parser computes the initial analysis of a sentence based on a short-time memory economy condition. Minimal Attachment proposes that the parser will choose the simplest (and quickest) way of analyzing the sentence, constructing a phrase-marker with the least possible nodes. Late Closure would be invoked when it is not possible to decide on a 
structure computing the number of nodes. Based on the Right Association Principle of Kimball (1973), Late Closure predicts that we "...attach new items into the clause or phrase currently being processed" (Frazier, 1987:562). An MA example is given in (2), in which the classic Bever's (1970) sentence is argued to be preferably parsed as a the Main Verb sentence in (a) than as the Reduced Relative clause in (b). The reason for that - Frazier's argument goes would be the parser's preference for less nodes, due to working memory limitations:

(2) a. [[The horse] [raced past [the barn]]... fell]

b. [[The horse[raced past [the barn]] fell]]

In (2a), the parser is garden-pathed when pursuing the least node strategy. Rapidly committing to this analysis, the parser analyzes the ambiguous verb "raced" as inflected in a simple past form. However, when it comes the millisecond-paced time in which the parser must integrate the "fell" verb form into the structure, the V structural slot is already occupied by the parser's wrong economic guess. According to Frazier's proposal, it must, then, start a second pass corrective analysis to establish the non-minimal reduced relative structure in (2b).

Late Closure may be exemplified in a structure as (1), above. Both the NP1 attachment (early closure) analysis, and the NP2 attachment structure (late closure), postulate equivalent number of nodes, ruling out the application of Minimal Attachment. The decision is taken on the basis of a "do what you are doing" strategy. According to Frazier, the parser chooses to append the relative clause to the phrase "currently being processed". The NP2 attachment is then argued to be universally preferred by the parser. However, an important study by Cuetos and Mitchell (1988) showed that - unlike in English - Late Closure was not the preferred strategy employed in Spanish equivalent sentences to (1). In response to questions such as "¿Quién estaba en el balcón?" (Who was on the balcony?), Spanish subjects showed a statistically significant tendency to early closure (the servant was on the balcony).

\section{A preliminary study}

A previous offline study (Maia \& Maia, 1999) tested the preferred processing strategy of Portuguese and English speakers facing ambiguous relative clause sentences. A questionnaire. 
containing 8 critical sentences with relative clauses, on the same basis as Cuetos \& Mitchell's (1988), was provided to three groups of subjects. The first group, made up of monolingual Portuguese speakers, answered the Portuguese version questionnaire.The second group, of monolingual English speakers, answered the English version of the questionnaire. The third group, of Portuguese native speakers with English as the second language, first answered the English questionnaire and then its Portuguese version. Comparing the parser's preference of the relative clause apposition through late closure (LC) or early closure (EC) strategies, the results showed that group I chose $\mathrm{EC}$ in a percentage of $76,25 \%$ against $22,5 \%$ of $\mathrm{LC}$, and that group 2 preferred the LC strategy over the EC in numbers of $81,0 \%$ against $19,0 \%$, showing no discrepancy to the expectations in relation to the findings in the literature. The third group curiously showed different preferences, suggesting a possible interaction between the strategies in the bilingual mind. The bilinguals preferred EC-65,0\% and LC-35,0\%, for the Portuguese version, and EC-57,5\% and LC-42,5\%, for the English version of the questionnaire. In order to clarify the questions raised from these results and to investigate whether the tendency found in group 3 would be reproduced in an equivalent group with English as L1 and Portuguese as L2, a new study was carried out.

\begin{tabular}{||l|l|l|l|l||}
\hline & Group 1 & Group 3 & & Group 2 \\
\cline { 2 - 5 } & Portuguese & Eng. & Port. & English \\
\hline \multirow{2}{*}{ EC } & $76,25 \%$ & $57,50 \%$ & $65,00 \%$ & $19,00 \%$ \\
\hline \multirow{2}{*}{ LC } & $22,50 \%$ & $42,50 \%$ & $35,00 \%$ & $81,00 \%$ \\
\hline$*$ & $1,25 \%$ & $0,0 \%$ & $0,0 \%$ & $2,0202 \%$ \\
\hline
\end{tabular}

* Void data

Tabel 1 - Study 1 Results

\section{The study}

Unlike Cuetos \& Mitchell (1988) in which processing strategies preferences of monolinguals in two languages (English and Spanish) is compared, the present study not only compares English and Portuguese monolinguals' parsing strategies but also observes 
parsing system interferences on L2 processing strategies by $\mathrm{L} 1$ parsing preferences. Thus, monolingual and bilingual subjects in both languages were tested on their comprehension of ambiguous relative clauses, such as (1). They were presented to a questionnaire based on Cuetos \& Mitchell (1988) experiment 1, in which the option to attach the relative clause to the first or to the second NP, respectively EC and LC, was given.

\subsection{Materials}

An off-line questionnaire, printed in both English and Portuguese (cf. appendix), of 20 items, containing 10 randomized distractors, unambiguous sentences with varied syntactic structures, and 10 experimental sentences formed according to the pattern NP1 of - NP2 - RC., extracted from Cuetos \& Mitchell's (1988) Appendix 1. Each sentence was followed by a question in which the answer would presumably have to be either the NP1 or the NP2. English and Portuguese examples of experimental sentences are provided below.

(3) a. John met the friend of the teacher [who was in Germany].

\section{NP1 NP2 RC}

- Who was in Germany?

b. João encontrou o amigo da professora [que estava na Alemanha].

NP1 NP2 RC

- Quem estava na Alemanha?

\subsection{Subjects}

There were a total of 40 subjects divided in four groups: (I) 10 monolingual Portuguese speakers with minimal or no knowledge of English, most of them undergraduate volunteers from Federal University of Rio de Janeiro, on their twenties; (II) 10 Portuguese/English bilinguals, mixed between English teachers and undergraduates from Federal University of Rio de Janeiro, also on their twenties; (III) 10 monolingual English speakers with minimal or no knowledge of Portuguese, north-american undergraduate students; and (IV) 10 English/Portuguese bilinguals, north-American English teachers who use Portuguese as a second language. Both subjects of group (II) and (IV) learned their second language after the age of 10, being considered, therefore, according to Fernández (1999), as "late learners", since puberty is commonly considered as the end of the critical period for language acquisition. (JOHNSON and NEWPORT 
1989,1991). Regarding L2 proficiency in group II, some of the subjects were teachers, therefore, supposedly displaying a good command of the language, and the others, except for one, reported having University of Cambridge certificates, indicating an intermediate to advanced level of proficiency. Group IV subjects allegedly learned Portuguese during extensive periods of living in Brazil.

\subsection{Procedures}

The subjects were given typed sheets containing a 20 item questionnaire. They were asked to answer the questions related to the sentences, making use of their speaker's intuition, without caring much about normative grammar aspects. It was made clear to them that there was not a single pattern to the questions and that their performance was not to be judged. Groups I and III were presented, respectively, with the questionnaires in English and in Portuguese. Bilingual subjects, were presented first with the questionnaire in L2 and then in Ll version. Thus, group IV answered the Portuguese questionnaire before its English version and group II first answered the English form and only then the Portuguese one. This precaution was taken in order to avoid recency effects from $\mathrm{L}_{1}$ procedures on $\mathrm{L} 2$.

\subsection{Predictions}

Group III results show no surprises. Studies about English speakers' preference on the attachment of the relative clause have already pointed to low attachment, agreeing with the Late Closure strategy and the Garden Path theory. This fact means, for instance, that the expected answer to question (3)a. would be the teacher. Group I, however, seems to go in the opposite direction. Previous works (MAIA \& MAIA, 1999 and RIBEIRO, 1999) have shown that, just like Spanish, Portuguese speakers tend to attach the relative clause to the higher NP, preferring the EC to solve the apposition of the relative clause. Thus, answers like the friend of the teacher would be the most likely to occur. Regarding the bilingual groups, II and IV, it is expected that the condition of a parsing system interfering on the other should occur. Again, as reported above, a previous study (MAIA \&MAIA, 1999) suggested that L1 routines may interfere on L2 parsing system. The data analysis of the samples collected from this study would be critical to investigate this psycholinguistic possibility. 


\subsection{Results and comments}

As indicated in the graph and table below, the data confirmed the predictions. Samples of Group III showed that $75,757 \%$ of the answers were in favour of LC and $22,222 \%$ of EC, with $2,02 \%$ of void data. Group I also met the expectations: $84,0 \%$ of the answers revealed the preference for the high apposition of the relative clause and only $14,0 \%$ for the low attachment, with $2,0 \%$ of void data. Group II and IV were presented to questionnaires in both languages. Portuguese/ English bilinguals answered to the English questionnaire with $53,0 \%$ of EC and $47,0 \%$ of LC and its Portuguese version with $74,0 \%$ of EC and $26,0 \%$ of LC. English/Portuguese bilinguals gave $56,0 \%$ of EC answers and $44,0 \%$ of LC answers on their Portuguese questionnaire and on its English version the numbers were $47,00 \%$ for EC and 53,00\% for LC. Comparing monolingual, group $I$, and bilingual, group II, Portuguese results, a decrease of EC samples is clearly noticeable. The same can be noticed on the numbers of LC, comparing the English results of groups III and IV. In order to verify whether this decrease indicates a significant proportion difference, those numbers were submitted to statistic analyses.

The difference between the portuguese questionnaire performances of Group I (Portuguese monolinguals) and Group IV (Portuguese spoken as L2 by native English speakers) was found to be statistically significant in a T-test analysis $(1,76764 \mathrm{E}-05, \mathrm{p}<0,1)$. Notice the decrease of EC scores and the increase of LC scores in Group IV in comparison to Group I, suggesting an interference of L1 (English) on L2 (Portuguese) in this group.

The difference in the English scores between Group III (English monolinguals) and Group II (English spoken as L2 by native Portuguese speakers) were also shown to be statistically significant in the T-test analysis $(8,34817 \mathrm{E}-06, p<0,1)$, suggesting the interference of the Portuguese EC strategy on the English spoken by the native portuguese speakers.

Interestingly, we also found statistically robust differences between the Portuguese of monolingual natives (Group 1) and the LI Portuguese of bilinguals (Group 2) $(0,084908274, \mathrm{p}<0,1)$ and between the English of monolingual natives (Group III) and the LI English of bilinguals (Group IV) $(0,999737419, \mathrm{p}<0,1)$. Even though, it is conceivable that $\mathrm{L} 2$ might be interfering with $\mathrm{L} 1$ in the bilingual's 
mind, we speculate that this result is probably due to experiment immediacy effects since bilingual subjects answered Ll questionnaires right after L2 questionnaires.

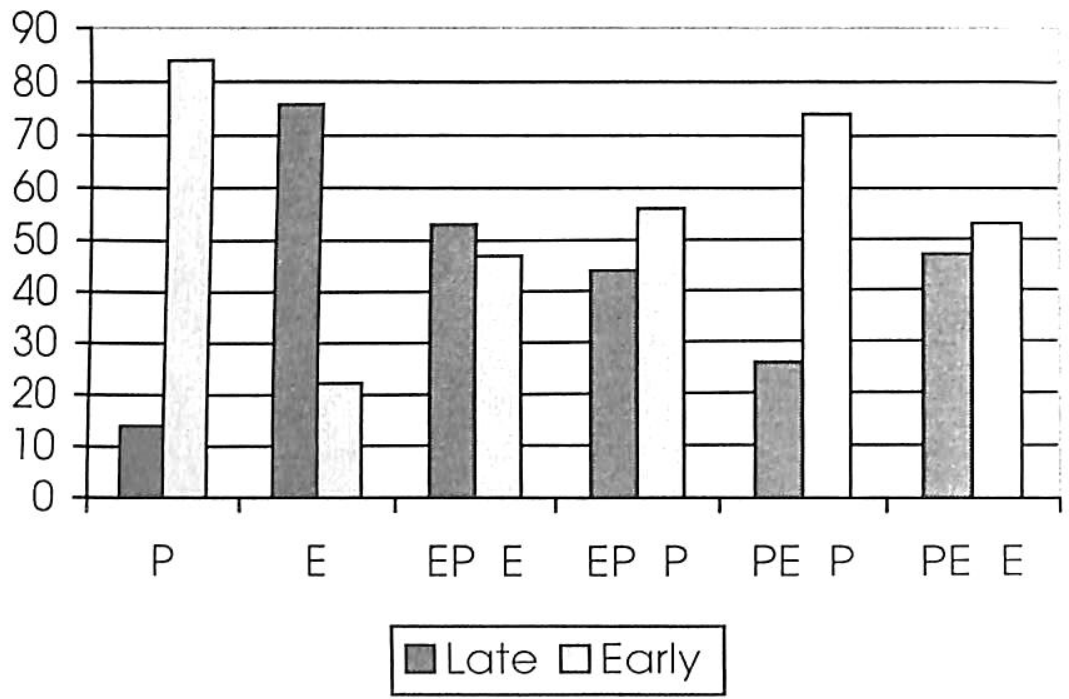

GRAPH 1 - RESULTS

\begin{tabular}{||l|l|l|l|l||l|l||}
\hline \multirow{2}{*}{} & Group I & \multicolumn{2}{|c|}{ Group II } & Group III & \multicolumn{2}{c|}{ Group IV } \\
\cline { 2 - 7 } & P & PE P & PE E & E & EP E & EP P \\
\hline \multirow{2}{*}{ EC } & $84,00 \%$ & $74,00 \%$ & $53,00 \%$ & $22,2222 \%$ & $47,00 \%$ & $56,00 \%$ \\
\hline \multirow{2}{*}{ LC } & $14,00 \%$ & $26,00 \%$ & $47,00 \%$ & $75,7575 \%$ & $53,00 \%$ & $44,00 \%$ \\
\hline$*$ & $2,00 \%$ & $0,0 \%$ & $0,0 \%$ & $2,0202 \%$ & $0,0 \%$ & $0,0 \%$ \\
\hline
\end{tabular}

* Void data.

Table 2- Study 2 Results 
Using an offline questionnaire task, our study showed that the preference for the high apposition of the relative clause (Early Closure), which is clear in the case of monolingual portuguese speakers (Group I), is not instantiated in the L2 Portuguese spoken by native English speakers, who did not display a significant preference to attach high, probably due to an influence of the processing strategy dominant in English, the Late closure. Likewise, our study also captured an effect of the Portuguese processing strategy Early Closure on English, as the comparison of groups III and II showed.

These results suggest that L1 processing strategies may become solidified and influence the processing of input in the L2. The implications of such findings may be crucial to understand why L2 acquisition by adults is usually less proficient than $\mathrm{L} 1$ acquisition. Our study provides evidence from Portuguese/English bilinguals to support Fernandez (1999) claim that UG may not be accessible to adult L2 learners because the processing strategies are not suitable, leading to sub-optimal representations of the grammar. In a future study we intend to collect on line data from our groups of bilinguals in order to discriminate between parsing and interpretation processes in the comprehension of relative clauses.

\section{Appendix}

\section{Portuguese questionnaire.}

1-Catarina encontrou pedras preciosas quando era criança.

- Quando ela encontrou tais pedras?

$\mathrm{R}:$

*2-Alguém atirou contra o empregado da atriz que estava na sacada.

- Quem estava na sacada?

$\mathrm{R}:$

*3-João encontrou o amigo da professora que estava na Alemanha.

- Quem estava na Alemanha?

$\mathrm{R}:$

4-Alessandra viaja todo mês a Paris por ser comissária de bordo.

- Quem é comissária de bordo?

$\mathrm{R}:$

*5-A polícia deteve a irmã do porteiro que estava em Minas Gerais.

- Quem estava em Minas Gerais?

$\mathrm{R}:$ 
6-Mariana arranjou um emprego quando descobriu a doença de seu pai.

- Quem esteve doente?

R:

*7-Amélia se corresponde com o primo do cantor que estava na igreja.

- Quem estava na igreja?

R:

8-Luis canta numa casa noturna todos os sábados.

- Quem canta todos os sábados?

$\mathrm{R}$ :

*9-O jornalista entrevistou a filha do coronel que sofrera um acidente.

- Quem sofrera um acidente?

$\mathrm{R}$ :

10-Patrícia liga para o namorado sempre antes de dormir

- Quando Patrícia liga para o namorado?

$\mathrm{R}$ :

*11-André jantou com a filha do porteiro que pertencia ao Partido Comunista.

- Quem pertencia ao Partido Comunista?

$\mathrm{R}$ :

12-Carla sempre come cachorro-quente durante o recreio.

- Quando Carla come cachorro-quente?

$\mathrm{R}$ :

*13-Marta saudou o irmão do padre que estava na escola.

- Quem estava na escola?

$\mathrm{R}$ :

14-O filho da empregada é muito inteligente.

- Quem é muito inteligente?

$\mathrm{R}$ :

*15-Esta tarde eu vi o filho do doutor que estava em nossa casa.

- Quem estava em nossa casa?

$\mathrm{R}:$

16-Vinícius estudou muito para poder vencer na vida.

- Por que Vinícius estudou muito?

$\mathrm{R}$

*17-Os meninos caçoaram da sobrinha da professora que estava no parque.

- Quem estava no parque?

R: 
AND BILINGUAL SPEAKERS OF PORTUGUESE AND ENGLISH

18-Paulo tem que acordar cedo por trabalhar longe de sua casa.

- Onde Paulo trabalha?

$\mathrm{R}:$

*19-Maria discutiu com o primo do leiteiro que esteve no Paraguai.

- Quem esteve no Paraguai?

R:

20-O amigo francês de Daniela é muito bonito.

- Quem é muito bonito?

$\mathrm{R}:$

\section{English questionnaire:}

1-Catarina found precious stones when she was a child.

-When did she find those stones?

$\mathrm{R}$ :

*2-Someone shot the servant of the actress who was on the balcony.

-Who was on the balcony?

$\mathrm{R}$ :

*3- John met the friend of the teacher who was in Germany.

-Who was in Germany?

$\mathrm{R}$ :

4-Alessandra every month travels to Paris because she is a flight attendant.

-Why does she travel to Paris every month?

R:

*5-The police arrested the sister of the porter who was in Minas Gerais.

- Who was in Minas Gerais?

$\mathrm{R}$ :

6- Maryanne got a job when she discoved her father illness.

Who had been sick?

R:

*7-Amelia exchanged letters with the cousin of the singer who was in the church. -Who was in the church?

R:

8-Louis sang every Saturday at a night club.

-Who sang every Saturday?

R:

*9-The journalist interviewed the daughter of the colonel who had had the accident.

-Who had had the accident?

R: 
10-Patricia always gives her boyfriend a call before going to sleep.

-When does she give him a call?

$\mathrm{R}$ :

*11-Andrew had dinner with the niece of the porter who belonged to the communist party.

-Who belonged to the communist party?

$\mathrm{R}$ :

12-Carla always eats hot-dog during the break.

-When does Carla eat hot-dog?

$\mathrm{R}$ :

*13-Martha cheered the brother of the priest who was in the school.

-Who was in the school?

$\mathrm{R}$ :

14-The son of the maid is very intelligent.

-Who is very intelligent?

$\mathrm{R}$ :

*15-This afternoon I saw the son of the doctor who was at our home.

-Who was at our home?

$\mathrm{R}$ :

16-Vinicius studied hard in order to succeed in life.

-Why did he study hard?

$\mathrm{R}$ :

*17- The boys poked fun at the niece of the teacher who was in the park.

-Who was in the park?

$\mathrm{R}$ :

18- Paul has to wake up early because he works far from home.

-Where does he work?

$\mathrm{R}$

*19-Mary argued with the cousin of the milkman who had been to Paraguai. -Who had been to Paraguai?

R:

20-The french friend of Daniela is very handsome.

-Who is very handsome?

$\mathrm{R}$ :

*experimental sentences. 


\section{References}

BEVER, T.G. (1970). The cognitive basis for linguistic structures. In Hayes 1970.

CHOMSKY, N. (1981). Lectures on government and binding. Dodrecht.

CHOMSKY N. \& LASNIK, H. (1993). The Theory of Principles and Parameters. In Jacobs, J. et alii (org.), Syntax, an International Handbook of Contemporary Research. Walter de Gruyter, Berlin, New York.

CUETOS, F., D.C. MITCHELL. (1988). Crosslinguistic differences in Parsing: Restrictions on the use of the Late Closure strategy in Spanish. Cognition, 30, 73-105.

FERNANDEZ, E.M. (1999) Processing strategies in second language acquisition: some preliminary results. In E.C. Klein and G. Martohardjono (eds.). The development of second language grammars: a generative approach. Amsterdam:John Benjamins.

FRAZIER, L. (1979). On comprehending sentences: Syntactic parsing strategies. Doctoral dissertation, University of Connecticut. Distributed by Indiana Linguistics Club.

FRAZIER, L. (1987). Sentence Processing: A tutorial review. In M. Coltheart (Ed.), Attention and performance XII: The psychology of reading (pp. 559-586). Hillsdale, NJ: Lawrence Erlbaum Associates.

JOHNSON, J \& E. NEWPORT. (1989). Critical Period Effects on Universal Properties of Language. Cognition 39, 215-258.

JOHNSON, J \& E. NEWPORT. (1991). Critical Period in second language learning. Cognitive Psychology, 21, 60-99.

KIMBALL, J. (1973). Seven Principles of surface structure parsing in natural language. Cognition 2:15-47.

MAIA, Marcus \& MAIA, Juliana. (1999). A aposição de orações relativas por falantes bilíngües de português e de inglês. Manuscrito, UFRJ

RIBEIRO, A.J.C. Um caso de não aplicação preferencial do Princípio de Late Closure. Trabalho apresentado no IX Congresso da ASSELRio. A aparecer nos Anais do Congresso, 1999. 